\title{
Stakeholder Contradictions in Early Stages of eHealth Efforts
}

\author{
Kirsti Askedal \\ Department of Health and Social Services \\ Municipality of Kristiansand \\ PO Box 417 Lund, 4604 Kristiansand, Norway \\ kirsti.askedal2@kristiansand.kommune.no
}

\author{
Leif Skiftenes Flak \\ Department of Information Systems \\ University of Agder \\ PO Box 422, 4604 Kristiansand, Norway \\ leif.flak@uia.no
}

\begin{abstract}
Use of information and communication technology (ICT) in healthcare has increased substantially over the past decades. Implementation of ICT in municipal health services (eHealth) involves a variety of stakeholders, and may lead to changes in the roles of providers and patients. Coordination, communication, early identification and involvement of key stakeholders in eHealth projects have been highlighted as important. However, research often takes a narrow perspective and pays scant attention to conflicting drivers. This study used a qualitative approach to identify and investigate contradictory stakeholder interests in the early phase of a municipal eHealth project. Analysis using Stakeholder Theory (ST) and Dialectic Process Theory revealed two important contradictions; 1) effective service versus efficient service and 2) technology enthusiasm versus reluctance to change. The analysis illustrated the usefulness of combining these theories in eHealth efforts. Implications from our research suggest that stakeholder management should be considered to prevent conflicts in eHealth projects.
\end{abstract}

\section{Introduction}

Healthcare services are facing substantial challenges the coming years. The age composition in the population changes and chronic diseases and diseases related to our lifestyle are expected to increase $[1,43]$. Providers of healthcare services are trying to come up with novel solutions to support more people at home, but it is challenging to secure funding and enough health personnel. Therefore, there is a need to identify new and innovative solutions to face these challenges [1]. Technology devices are increasingly being integrated into healthcare as an intervention to help support people at home [26].

Technology implementations are changing the roles of healthcare consumers and providers, and make complex personal, social and organizational arrangements even more complex [22]. Increased division of labour has been highlighted as an important effect as technology increases General Practitioner's (GP) work burden and undermines their professional autonomy [25]. Negative effects on resource usage is also reported when providing care by electronic communication for patients with chronical diseases [2]. Place- and time dependant delivery is another area where healthcare may be reshaped as it intervenes with traditional care characteristics [37]. Interorganizational systems force different stakeholders to cooperate, even though they can be seen as competitors with different interests and attitudes [31]. This complexity requires coordination and communication among different stakeholders [40] to ensure that technology supports the needs and values of key stakeholders.

Existing research of eHealth-projects have mostly been done from a single perspective, that of health personnel $[20,36]$, and pay scant attention to complex drivers. As technology use in healthcare can lead to new ways of working, a perception of shifts of professional roles can lead to conflict. The research of Segar et al [33] highlights the potential areas of boundary conflicts when implementing technology to support patients with long term conditions. Here, nurses working with technology suggested new roles and identities, but nurses providing traditional health services and GP's were sceptical and ambivalent about the contribution, and communicated a sense of protectiveness for retaining of their positions [33].

In contrast to private sector, public sector has been reported to have a more diverse body of stakeholders [42]. A crucial activity in projects in public organizations is therefor arguably the stakeholder analysis [42]. This is essential for early identification and potential inclusion of key stakeholders to understand and address important values, drivers and goals [40, 37], as well as understanding suitable combinations of non-technological and technological resources that can provide sustainable benefits $[42,10]$. 
In a research domain similar to eHealth, i.e. eGovernment, an analysis of key stakeholders using Stakeholder Theory (ST) and Dialectics revealed conflicts with potential to inhibit successful project outcomes [13]. This study applies the same analytical framework in the field of eHealth, to reveal possible contradictions between stakeholders in early stages of eHealth efforts.

The research question for this study is therefor: Which contradictory stakeholder interests can be found in the concept phase of a municipal eHealth project?

\section{Background and theory}

Theory is used for two purposes in this study. First, the eHealth literature is used as a context. Second, ST and Dialectic Process Theory are presented as an analytic lens for this study.

\section{1. eHealth}

Martin, Kelly, Kernohan, Bernadette McCreight and Nurgent [26] argue that there is considerable conceptual confusion regarding terminology related to research on ICT and healthcare. Terms like telecare, telehealth, telemedicine, eHealth and mHealth are used interchangeably, and various definitions of these concepts exists $[17,34,44]$.

Given the different use of terminology related to ICT in healthcare, Eysenback's [11] definition on eHealth is adopted in this study as it covers both the dimension of technology development and the way of thinking to improve healthcare delivery in a global perspective: "e-health is an emerging field in the intersection of medical informatics, public health and business, referring to health services and information delivered or enhanced through the Internet and related technologies. In a broader sense, the term characterizes not only a technical development, but also a state-of-mind, a way of thinking, an attitude, and a commitment for networked, global thinking, to improve health care locally, regionally, and worldwide by using information and communication technology" [11, p.2-3].

As Eysenback [11] points out, the development of eHealth technologies involves more than designing a product or service, it also has a social dimension for improving the healthcare services. When creating new technology in healthcare services, it is important to know how the process of healthcare delivery actually runs, e.g. how payment is organized and who the key stakeholders are. Involvement of stakeholders is seen as important for reflection on goals, drivers and values of the developed eHealth technologies as this will illuminate the interdependencies between people, their sociocultural environment, technology and the infrastructural organization of healthcare [40].

Implementing technology into health- and care services challenges the organizations, with technological possibilities on one side, and current service delivery on the other side[10]. Barriers for technology implementation seem to remain unchanged, like increased time and effort for health personnel and lack of user involvement in development of technology. Incorporation of experiences from earlier projects are reported as appropriate to avoid well known barriers and secure successful implementation [20]. Meanwhile, in the field of eHealth it seems difficult to realize the expected effects of using technology $[10,18,19]$ and varying degrees of effects for patients and health personnel are reported [35, 44].

Careful communication and coordination is required among the different stakeholders when introducing eHealth technologies, but seems hard to realize in practice [40]. Although most eHealth studies involve a number of actors or entities, an explicit stakeholder focus is often missing [39]. Van GemertPijnen, Nijland, van Limburg, Ossebaard, Kelders and Eysenbach [40] argue that "as long as the need to create a better fit between technological, human, and contextual factors continues to go unaddressed, the uptake and impact of eHealth technologies will remain at the very least poor, and at best undecided"

\subsection{Stakeholder theory}

The focus on stakeholders and stakeholder management has received much attention in several research areas since the publication of the book Strategic Management: A stakeholders Approach by Freeman in 1984. ST focuses on the stakeholders interests rather than the compromises that sometimes have to be made $[15$, p.28]. It's important to understand how the relationships between different groups with ownerships in a business or service work, because value is created when these groups interact. It is the manager's job to build and maintain these relationships, so if conflicts of interests occur the manager needs to find a solution that offers an optimal alignment of interest in order to realize an organization's goals [15].

Freeman, Harrison, Wicks, Parmar and De Colle [15] argue that all stakeholders have equal right to act to protect their interests, but they are not equally important over time. To avoid stakeholder restitution, interests of key stakeholders should be aligned over time.

ST can be, and have been used in three different approaches [9]: 
- Descriptive approach; presents models for describing organizations, and competitive interests of stakeholder value observed in reality.

- Instrumental approach; a framework for investigating possible connection between the realization of performance goals and management of stakeholders.

- $\quad$ Normative approach; the stakeholders are persons or groups with justified interests of corporate activity, have interests of intrinsic value and appeal to underlying concepts e.g. a group utilitarianism or "rights".

Donaldson and Preston [9] argue that the core of the theory is normative and goes beyond the fact that organizations have stakeholders, and that the three aspects are nested within each other.

Even though Freeman et al [15] and Donaldson and Preston [9] focused on private firms and businesses, ST has later been used in public sector contexts. Flak and Rose [14] e.g. used ST in the eGovernment domain, and stakeholder theory has been applied in studies within healthcare management [3]

When searching for research in the field of eHealth, we found few studies using this theory. A few notable exceptions exist. Mengesha, Kebede, Garfield and Musa's study [28] used ST in a Telemedicine project in Ethiopia. Here, ST resulted in a robust analysis and an explanatory way to illuminate the different interests among the stakeholder groups and how it affected the use of Telemedicine. Pagliari [30] provided a list of different stakeholders related to eHealth e.g. health system managers, IT experts, healthcare organizations, health professionals, policy makers, and vendors. A recent review of process modelling in eHealth conducted by Garmann-Johnsen and Hellang [16] suggests a typology of 4 stakeholder groups; acceptors, providers, controllers and supporters.

Based on the above, this study will use a descriptive approach to ST to address the research questions.

\subsection{Dialectic process theory}

Dialectic process theory is one of four basic theories which Van de Ven and Poole [38] suggest can be used for explaining processes of changes in organizations. The theory assumes that "the organizational entity exist in a pluralistic world of colliding events, forces, or contradictory values that compete with each other for domination and control. These oppositions may be internal to an organizational entity because it may have several conflicting goals or interest groups competing for priority"'[38, p.517].

Thinking in terms of contradiction is the key element in dialectical analysis [27], and requires two or more clear entities that express this opposition by engaging and confronting each other in conflict [38]. Figure 1 illustrates how a contradiction occurs; between two opposite aspects, thesis and antithesis [13].

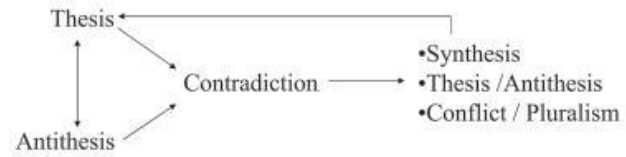

Figure 1. Dialectic process lens to development and change (in Flak et al [13], adapted from Van de Ven and Poole, [38]).

The starting point in dialectic process theory is the contradiction, which is seen as a whole, and the only way to learn about the contradiction is to investigate the aspects (thesis and antithesis) and their relation. It is not possible to learn about the contradiction by investigating only one aspect. Thesis cannot be fully understood without considering the antithesis [27]. A solution to the contradiction can either turn into 1) a synthesis and then be a new thesis, as the dialectic process continues, or 2) continue in the organization as the existing state of affairs, or survival of only one of the aspects, or 3) converts into conflict [38].

There is an increasing interests of research related to eHealth innovation as this is a growing field, and many of the studies investigate problems or success factors related to implementation [20]. Cho, Mathiassen and Robey [6] continue the line of research related to telehealth innovation by investigating the relationship between adoption of technology and organizational resilience with use of dialectic process theory. For understanding the future success of eHealth innovation in a large extent, Cho et al [6] suggest a dialectical analysis of the involved contradictions.

Flak, Nordheim and Munkvold [13] have shown the use of dialectics in stakeholder analysis in a Government context to uncover the many heterogeneous stakeholders and expected contradictions. We have not seen studies of stakeholder contradictions in eHealth and therefor seek to explore the nature and impact of the phenomenon in this context using dialectic process theory and ST as an analytical lens.

\section{Method}

This section describes the research method used in the study and the outlines case. 


\subsection{Research method}

A qualitative research approach [29] was adopted for addressing the research question. First, a review of reports, research and national strategies and guidelines was conducted to get an overview of the field. Second, a list of possible key stakeholders was compiled and used as a starting point for observational study. The observational study was used for identifying stakeholders and understanding their workflows. Third, fifteen focus groups were conducted by one of the researchers in February to April 2016. The interviews lasted from 1-1,5 hours and were recorded. An interview guide was used to highlight relevant themes for the objectives of the study. The content from the interviews were coded by one of the researchers into themes from a stakeholder perspective, and contradictory interests were identified through several discussions between the two researchers.

Respondents were selected from different levels of health and social services in a municipality in the southern part of Norway and included user representatives. The list of key stakeholders was used in the recruitment process and the respondents were recruited by their managers. This may cause a potential for social bias, but because the majority of the respondents are working in shifts, and their managers are responsible for maintaining the service and know how to provide backup, it was decided to be the best way to recruit respondents. Some key stakeholders were discovered during the interviews and included in the project. There was a great enthusiasm among the respondents and they expressed gratitude for being included. After fifteen focus groups, little new information arose.

Table 1 provides an overview in terms of organizational units and position of the respondents.

Table 1. Overview of respondents.

\begin{tabular}{|l|l|l|l|}
\hline $\begin{array}{c}\text { Organization } \\
\text { al Units }\end{array}$ & \multicolumn{1}{|c|}{ Position } & $\begin{array}{c}\text { Nr. of } \\
\text { Intervie } \\
\text { ws }\end{array}$ & $\begin{array}{c}\text { Nr. of } \\
\text { Respon } \\
\text { dents }\end{array}$ \\
\hline $\begin{array}{l}\text { Out-of-hours } \\
\text { emergency } \\
\text { primary care }\end{array}$ & $\begin{array}{l}\text { Health } \\
\text { personnel }\end{array}$ & 1 & 2 \\
\hline $\begin{array}{l}\text { Telemedicine } \\
\text { Centre }\end{array}$ & $\begin{array}{l}\text { Health } \\
\text { personnel }\end{array}$ & 1 & 10 \\
\hline Home care & $\begin{array}{l}\text { Health } \\
\text { personnel incl. } \\
\text { professionals } \\
\text { association } \\
\text { representatives } \\
\text { and health and } \\
\text { safety }\end{array}$ & 5 & 17 \\
\hline
\end{tabular}

\begin{tabular}{|l|l|l|l|}
\hline & representatives & & \\
\hline Home care & $\begin{array}{l}\text { Technical } \\
\text { personnel and } \\
\text { system } \\
\text { administrator }\end{array}$ & 2 & 4 \\
\hline $\begin{array}{l}\text { Health and } \\
\text { care }\end{array}$ & $\begin{array}{l}\text { Service } \\
\text { managers }\end{array}$ & 3 & 15 \\
\hline $\begin{array}{l}\text { Health and } \\
\text { social service }\end{array}$ & Top managers & 1 & 2 \\
\hline $\begin{array}{l}\text { Mental health } \\
\text { and social } \\
\text { work }\end{array}$ & $\begin{array}{l}\text { Service } \\
\text { managers }\end{array}$ & 1 & 4 \\
\hline $\begin{array}{l}\text { Senior Citizen } \\
\text { Council }\end{array}$ & $\begin{array}{l}\text { User } \\
\text { representatives }\end{array}$ & 1 & 10 \\
\hline Total & & 15 & 64 \\
\hline
\end{tabular}

\subsection{Case description}

Norway is one of the Scandinavian countries, and has roughly five million inhabitants spread across nearly four hundred thousand square kilometers. Norway has a parliamentary democracy, and is divided in three different administrative levels: state, 19 counties and 428 municipalities.

The healthcare system can be seen as semidecentralized, where the responsibility for specialist care lies with the state. Municipalities have freedom in organizing health services and are responsible for provision and funding of primary care (including physiotherapy and nursing, rehabilitation, and out- ofhour's emergency primary care). Primary care is financed from specific purpose- and block grants from the central government and municipal taxes [32].

The Ministry of Health is responsible for supervision and regulation of the system, but several tasks are delegated to subordinate agencies e.g. the Directorate of Health. The organizational structure is built on the principle of equal access to services for all inhabitants regardless of geographical location and economic or social status [32, p. 15].

The last few years' focus on healthcare services has been on improvement of coordination between healthcare providers, patient safe issues, and quality of care. As is typical in the Scandinavian countries, patients are more often than not organized, mostly related to particular diseases or disease groups, and employees are organized in trade unions and professional associations[32].

In summer 2015, a municipality on behalf of a region in the southern part of Norway, was asked by the Norwegian Directorate of Health to establish a central for receiving and evaluating safety alarms (henceforth referred to as the Response Central). The 
project received some financial support from the Norwegian Directorate of Health to procurement of technical solutions, but had to finance the remaining themselves. As the management of safety alarms today is mostly conducted by healthcare professionals working directly with patients in homecare services, the initiative will lead to a major change in workflow and provision of services.

As a starting point, it was decided to analyze current service and future needs, with a goal to provide recommendations for optimal organization of the service, and identify if this service can be seen in connection with similar services in the municipality (e.g. Out-of-hours emergency primary care or Telemedicine Centre). The analysis can be seen as a part of concept phase in a framework for project management, built on the well-known project management methodology; Prince2.

\section{Results}

In addition to the stakeholders introduced in the table of respondents (Table 1), the following key stakeholders was identified (illustrated in Figure 2): patients and their relatives, other municipalities in the region seen as collaboration partners, politicians, technology vendors and the Directorate of Health. The stakeholders were identified during the analysis based on input from the respondents and information from the document study.

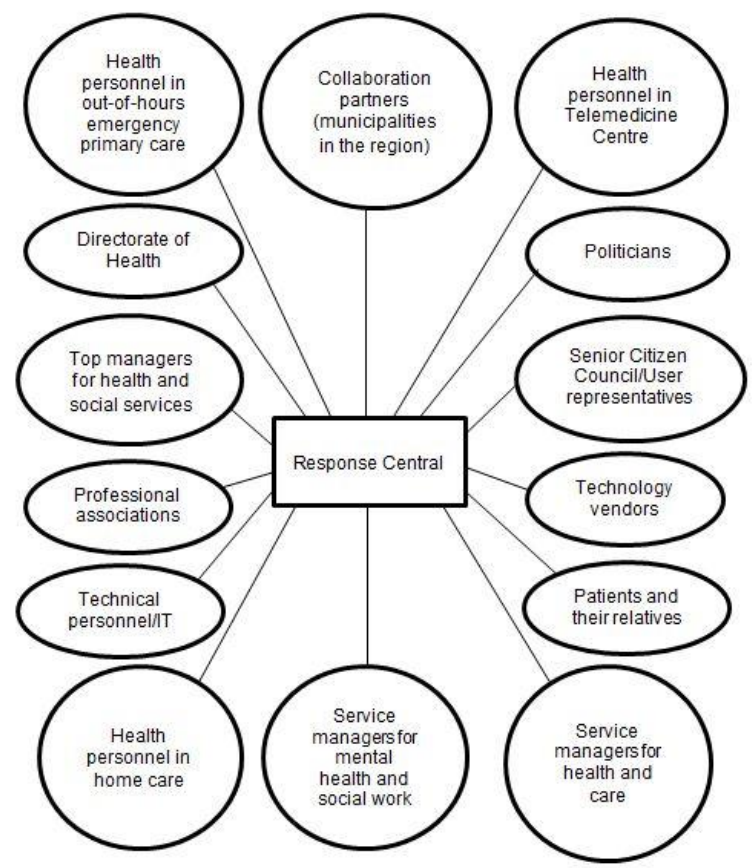

Figure 2. Stakeholder map.
The Norwegian Directorate of Health is the initiator of the project, and progress and results will be reported at a national level. Technology vendors are natural stakeholders in this project as the Response Central is dependent on technology for delivering the expected services, e.g. devices like safety alarms, and a system for routing, receiving and documentation. Politicians are also identified as stakeholders, as they allocate funding and must be able to defend the money spent in relation to the new service. Patients and their relatives are end-users of this service, and an important stakeholder- group, which in this study are represented by the Senior Citizen Council. The last key stakeholder group is collaboration partners, which in this case are other municipalities in the region. Based on the objective of mapping current service and future needs, it was considered adequate to conduct focus groups of the respondents listed in table 2, even though some more key stakeholders where identified through the process (Figure 2) and possibly would have added more interesting perspectives to the case.

In addition to questions related to experience and future needs, all respondents were asked about their thoughts (positive and negative) about the Response Central initiative, and if they had some input on how to establish the service in a good way. The Dialectic Process Theory was used to identify contradictory interests (presented in Tables 2 and 3).

Contradictions were found in two distinct areas: 1) effective (adequate to accomplish a purpose [7]) service versus efficient (performing or functioning in the best possible manner with the least waste of time and effort [8]) service and 2) technology enthusiasm versus reluctance to change. Contradiction one can be seen as a main class of contradictions, exemplified with different sub- contradictions, i.e. a) personalized service versus quick and efficient service, b) in-house service delivery versus collaborative service delivery and c) technicians responsible for technology versus health professionals responsible for technology. Explanations of the different sub- contradictions of effective service versus efficient service are presented in Table 2. 
Table 2. Examples and explanations of contradictions related to effective service versus efficient service.

\begin{tabular}{|c|c|c|}
\hline & $\begin{array}{l}\text { Thesis } \\
\text { (effective } \\
\text { service) }\end{array}$ & $\begin{array}{l}\text { Antithesis } \\
\text { (efficient service) }\end{array}$ \\
\hline $\begin{array}{l}\text { Contradiction } \\
\text { 1a: personalized } \\
\text { service versus } \\
\text { quick and } \\
\text { efficient service }\end{array}$ & $\begin{array}{l}\text { Personalized } \\
\text { service: manual } \\
\text { work performed } \\
\text { by a service } \\
\text { provider in } \\
\text { serving a } \\
\text { customer one- } \\
\text { to- one at } \\
\text { customer's site } \\
{[4]}\end{array}$ & $\begin{array}{l}\text { Quick and } \\
\text { efficient service: } \\
\text { performing or } \\
\text { functioning in the } \\
\text { best possible } \\
\text { manner with the } \\
\text { least waste of } \\
\text { time and effort [8] }\end{array}$ \\
\hline $\begin{array}{l}\text { Contradiction } \\
\text { 1b: in-house } \\
\text { service delivery } \\
\text { versus } \\
\text { collaborative } \\
\text { service delivery }\end{array}$ & $\begin{array}{l}\text { In-house } \\
\text { service } \\
\text { delivery: } \\
\text { conducting an } \\
\text { activity or } \\
\text { operation within } \\
\text { the } \\
\text { organization, } \\
\text { using its own } \\
\text { employees and } \\
\text { time to keep a } \\
\text { department or } \\
\text { organization } \\
\text { activity [21] }\end{array}$ & $\begin{array}{l}\text { Collaborative } \\
\text { service delivery: } \\
\text { independent } \\
\text { individuals and } \\
\text { organization } \\
\text { combining their } \\
\text { human and } \\
\text { material resources } \\
\text { so they can } \\
\text { accomplish } \\
\text { objectives they } \\
\text { are unable to } \\
\text { bring alone [24, p. } \\
\text { 183] }\end{array}$ \\
\hline $\begin{array}{l}\text { Contradiction } \\
\text { 1c: technical } \\
\text { personnel } \\
\text { responsible for } \\
\text { technology } \\
\text { versus health } \\
\text { personnel } \\
\text { responsible for } \\
\text { technology }\end{array}$ & $\begin{array}{l}\text { Technical } \\
\text { personnel } \\
\text { responsible for } \\
\text { technology: } \\
\text { technical } \\
\text { personnel } \\
\text { arrange and are } \\
\text { responsible for } \\
\text { technology in } \\
\text { the patients } \\
\text { home }\end{array}$ & $\begin{array}{l}\text { Health personnel } \\
\text { responsible for } \\
\text { technology: } \\
\text { health personnel } \\
\text { have knowledge } \\
\text { and skills to take } \\
\text { care of technology } \\
\text { in the patients } \\
\text { home }\end{array}$ \\
\hline
\end{tabular}

Due to space limitations, only one of the three subcontradictions (1a: personalized service versus quick and efficient service) is used to illustrate contradiction 1: effective service versus efficient service (if permitted, evidence related to contradiction $1 \mathrm{~b}$ and $1 \mathrm{c}$ can be made available in an appendix). In addition to contradiction 2: technology enthusiasm versus reluctance to change. Table 3 provides an overview of the contradiction and stakeholders involved.
Table 3. Overview of contradictions and stakeholders involved.

\begin{tabular}{|c|c|c|}
\hline & $\begin{array}{l}\text { Contradiction } \\
\text { 1a: } \\
\text { personalized } \\
\text { service versus } \\
\text { quick and } \\
\text { efficient service }\end{array}$ & $\begin{array}{l}\text { Contradiction 2: } \\
\text { technology } \\
\text { enthusiasm versus } \\
\text { reluctance to } \\
\text { change }\end{array}$ \\
\hline $\begin{array}{l}\text { Stakeholders } \\
\text { involved }\end{array}$ & $\begin{array}{l}\text {-Health personnel } \\
\text { in home care, } \\
\text { Service managers } \\
\text { for health and } \\
\text { care, Service } \\
\text { managers for } \\
\text { mental health and } \\
\text { social work, Top } \\
\text { managers (thesis) } \\
\text {-Health personnel } \\
\text { in home care, } \\
\text { Service managers } \\
\text { for health and } \\
\text { care, Service } \\
\text { managers for } \\
\text { mental health and } \\
\text { social work, Top } \\
\text { managers, User } \\
\text { representatives } \\
\text { (antithesis) }\end{array}$ & $\begin{array}{l}\text {-Health personnel } \\
\text { in home care, } \\
\text { Service managers } \\
\text { for health and care, } \\
\text { Service managers } \\
\text { for mental health } \\
\text { and social work, } \\
\text { Top managers, } \\
\text { User } \\
\text { representatives, } \\
\text { (thesis) } \\
\text { - Health personnel } \\
\text { in home care } \\
\text { (antithesis) }\end{array}$ \\
\hline Thesis & $\begin{array}{l}\text { Personalized } \\
\text { service (effective } \\
\text { service) }\end{array}$ & $\begin{array}{l}\text { Technology } \\
\text { enthusiasm;persons } \\
\text { who are exited } \\
\text { about technology } \\
\text { [45] }\end{array}$ \\
\hline Antithesis & $\begin{array}{l}\text { Quick and } \\
\text { efficient service }\end{array}$ & $\begin{array}{l}\text { Reluctance to } \\
\text { change ; action } \\
\text { taken by } \\
\text { individuals and } \\
\text { groups when they } \\
\text { perceive that a } \\
\text { change is occurring } \\
\text { as a threat to } \\
\text { them[5] }\end{array}$ \\
\hline Outcome & $\begin{array}{l}\text { Emerging } \\
\text { synthesis. } \\
\text { Temporary focus } \\
\text { on redefining the } \\
\text { specific service }\end{array}$ & $\begin{array}{l}\text { Thesis prevails. } \\
\text { Continue to } \\
\text { implement } \\
\text { technology with } \\
\text { focus on benefits } \\
\text { realization and } \\
\text { change } \\
\text { management }\end{array}$ \\
\hline
\end{tabular}

As listed in Table 3, the contradiction can be found within stakeholder groups (both thesis and antithesis) and between stakeholder groups. In the next session, the contradictions will be discussed and examples from the interviews used to illustrate thesis and antithesis. 


\section{Discussion}

\section{Contradiction 1: personalized service versus quick and efficient service}

This contradiction proved to be a core theme in almost every interview. It is understandable that there is substantial engagement related to the Response Central as it changes the workflow for both health personnel and service managers and also the delivery of services to end-users.

Thesis of contradiction 1a (personalized service):
"The positive about safety alarms today is that we
know the end-users. It will be very difficult for a
common central (ref. Response Central) when they
don't know the end-users. I think it will be a bad
organization, and I cannot see how this will be
successful... We know what to do if we receive the
alarm, we will investigate what has happened and
all that...but if they are managing it from a common
central, I cannot see quite how... what's the idea?"
(Health personnel in home care)
Antithesis of contradiction1a (quick and efficient
service):
- "The way it is today, it takes time before they are
calling back (when safety alarms are released). Here
(ref. Response Central), you will get a response
almost immediately"
(User representative from Senior Citizen Council).
- "If an alarm that really matters is released... if it
had been me who needed help, it would have been
the same who responded it, if I only received help,
and I had confidence in that those who came to me
have expertise to give me the help that I needed"
(Service manager for health and care).

These quotations show contrast and represent different aspects of the contradiction. The interviews provided rich empirical data supporting this contradiction and the involved stakeholders. The above are just examples to illustrate and support the contradiction.

Due to the high number of stakeholders supporting the thesis, several different causes can be envisioned. Healthcare professionals are trained to support and give help to people based on a holistic view of humanity. They have known many of their patients for a long time, and strive to cover their basic needs (physical, social, psychical and spiritual/cultural). As this has been the practice of service provision for many years, this initiative can be seen as a threat to both profession and practice.

Service managers and top managers are responsible for how the service is run, related to e.g. quality, economy and as an employer. They know their employees and rely on their expertise to provide expected services to a large group of patients. As the interviews were conducted in the concept phase of the project, there were little specific information about how the new service will be financed, how it will affect the employees, and whether it will lead to increased service quality or not. This uncertainty may have affected the perspective of service/top managers and also for health personnel, as they are responsible for service delivery to people in need. Further, it has been argued to be common to fear the unknown[23].

The only difference in stakeholders involved in the thesis and antithesis is the user representatives (antithesis). It was an interesting discovery that the stakeholder group which represents the end-users was warmly welcoming the Response Central. This group emphasized the importance of quick and efficient service rather than personalized service. This may be based on experiences of e.g. slow response to released alarms or interruption of healthcare's visiting patients by telephones or safety alarms resulting in loss of focus on the initial patient. By organizing the service differently, they think it could provide professional management of safety alarms, and also increase the quality of the provided home care services.

Health personnel have a high work load and express stress and dissatisfaction when safety alarms and telephones interrupt their work. From this point of view, some can see the Response Central as an aid to ease their workload. Service managers have a broader perspective on their services, and are concerned about the demographical changes. If it is possible to increase the effectiveness and efficiency with use of technology and organizational changes, some are positive and willing to support such action. Effective and efficient services are also important for top managers and this may be one of the reasons for representing the antithesis.

Through this brief discussion, different causes for thesis and antithesis are suggested. It is particularly interesting to observe that health personnel claims to speak for the good of the patient (thesis), when noting that the user representatives had a very different idea about what constitutes a good service for the end-users.

In reality, the antithesis had more power than thesis, due to the decision of establishing the Response Central. However, it is important to manage the involved stakeholders and the different aspects, because value is created when these groups interact. There is ongoing work focusing on clarify expectations and defining the specific service, with distinct criteria for the service. This can be seen as a step in the direction of integrating personalized service (thesis) and quick and efficient service (antithesis). 
Contradiction 2: technology enthusiasm versus reluctance to change

As presented in Table 3, stakeholders from all the different levels of health and social services are involved in the thesis of contradiction 2 (technology enthusiasm). It is interesting to reveal only health personnel from home care involved in the antithesis of contradiction 2 (reluctance to change).

Thesis of contradiction 2 (technology enthusiasm):
- We are whining about the technology, because it is
extremely important to us» (Service manager for
mental health and social work)
- When asking the user representatives what they
think of the future and technology, several say in
unison: «Implement technology everywhere it can be
used! (User representative from Senior Citizen
Council)
Antithesis of contradiction 2 (reluctance to change):
"If the Response Centre is going to be centralized...
then I won't work anymore. It will not be exciting to
work as a health personnel if someone else are going
to tell us what we should do» (Health personnel in
home care)

The user representatives were enthusiastic about technology and related their enthusiasm to patient empowerment and that people would be able to live longer and safer in their own homes. Over the past few years, substantial attention has been put on informing the user representatives about the possibilities new technology may bring. Based on the enthusiasm for technology it appears that user representatives have accepted the value of, and benefits from, use of new technology in this context.

During the interviews with health personnel, all respondents suggested new features and technology that would have helped them in their work, either for better security and quality of the care (e.g. monitoring at night instead of personal visit- who can be noisy and wake up the patient) or for better resource use (e.g. bidirectional communication through the safety alarm attached to the patient, rather than an extra drive to the patient revealing a false alarm).

Service managers for health and care expressed enthusiasm for technology in relation to the demographical changes and the challenge of how to provide future services. They thought there would be organizational and professional change in service delivery within few years, and were eager to use the next years preparing for this. Despite their enthusiasm, they emphasized the heavy work-load in today's service delivery and that eHealth project managers need to communicate a clear vision of possible effects for optimal organizational involvement.
Service managers for mental health and social work are responsible for people with substance abuse, mental disorders and the mentally retarded. Among others, their employees are taking care of children with epilepsy and people who are violent due to drug problems. In these cases, they use technology like epilepsy alarm or safety alarms for employees. They must rely on- and are dependent on these devices, as it can lead to serious consequences if the technology does not work. When thinking of their patient groups they were creative, suggesting early introduction of technology, and hoping for a further development of sensors and devices.

From the perspective to top managers, a clear goal of the future service, with technology included, was communicated. This focus was related to expertise and quality, as the technology lead to possibilities and organizational changes in service delivery. A robust technical platform was also mentioned as a dimension when considering implementation of technology.

In addition to be enthusiastic about new technology, health personnel in home care expressed reluctance to change in varying degree in the majority of the interviews. This is seen as the antithesis in contradiction 2. Acceptance and resistance is a wellknown contradiction, also in the health context [41]. There can be several reasons for this perspective in this specific case. One motive can relate to the same cause for thesis (personalized services) in contradiction 1a, a threat to both profession and practice as this project and future implementation of technology may lead to new ways of working and a perception of shifts of professional roles. Another motive for reluctance to change may be related to insecurity of values and effect, as the interviews were conducted in the early stage of the project when a clear business plan had not yet been developed and communication failed to motivate the initiative. It is an interesting finding that some of the same health personnel who were enthusiastic towards technology expressed reluctance to change. The observations and interviews revealed that health personnel were concerned about their heavy workload. From their perspective, it appeared difficult to accept that technology implementation and change in workflow would help to relieve heavy workload, and assist service delivery in a more efficient way. Previous research points out that an innovation of a service may be limited depending of the stakeholder group, i.e. health personnel responsible for their clinical work. This perspective may coincide with the research, and be a natural reason for limitation in health personnel's thoughts for the reality of the challenges the healthcare service soon will be facing.

Even though we discovered a general technology enthusiasm from the different stakeholder perspectives, 
the discussion showed different values and drivers behind the enthusiasm. While this complexity poses challenges, our unveiling of details is considered to bring considerable opportunity for future implementations of eHealth. We know technology devices are increasingly being integrated into healthcare [26]. Due to the contradiction uncovered by our analyses, we argue that future eHealth projects should be managed in a strategic way to communicate values, benefits and to avoid stakeholder resistance.

The interviews representing different perspectives provided an in-depth understanding of how healthcare service was provided in this specific case, and gave a sound basis for dialectic analysis. Hopefully, the dialectic analysis in the early stage of the project can empower the organization to address the contradictions by improving communication and coordination of the different stakeholders.

\section{Conclusion}

This study has investigated the potential for stakeholder conflicts in eHealth efforts. A qualitative research approach was adopted to get in-depth understanding of an eHealth effort and involved stakeholders. Fifteen focus groups were conducted in the early phase of a project related to establishment of a Response Central for safety alarms. Interview data were coded into different themes from a stakeholder perspective, and the dialectic process theory was used

\section{References}

[1] K. Barnett, S. W. Mercer, M. Norbury, G. Watt, S. Wyke and B. Guthrie, "Epidemiology of multimorbidity and implications for health care, research, and medical education: a cross-sectional study", Lancet, 380 (2012), pp. 37-43.

[2] F. F. Berkhof, J. W. K. Van Den Berg, S. M. Uil and H. A. M. Kerstjens, "Telemedicine, the effect of nurseinitiated telephone follow up, on health status and healthcare utilization in COPD patients: A randomized trial", Respirology, 20 (2015), pp. 279-285.

[3] J. D. Blair and C. J. Whitehead, "Too Many On The Seesaw: Stakeholder Diagnosis And Managemen", Journal of Healthcare Management, 33 (1988), pp. 153.

[4] Businessdictionary.com, Personal Service, 2016.

[5] Changingminds.org, Resistance to Change, 2016.

[6] S. Cho, L. Mathiassen and D. Robey, "Dialectics of resilience: A multi-level analysis of a telehealth innovation", Journal of Information Technology, 22 (2007), pp. 24-35.

[7] Dictionary.com, Effective, 2016.

[8] Dictionary.com, Efficient 2016.

[9] T. Donaldson and L. E. Preston, "The Stakeholder Theory of the Corporation: Concepts, Evidence, and to identify contradictory interests. Two contradictions are presented; 1) personalized service versus quick and efficient service, exemplified with different subcontradictions, and 2) technology enthusiasm versus reluctance to change.

Among other, it is interesting that health personnel speak for the good of the patient (personalized service), but user representatives have very different perceptions about what constitutes a good service (quick and efficient service). It is also notable that stakeholders from all the different levels of health and social services, including user representatives, were enthusiastic towards new technology. Health personnel in home care are the only stakeholder group who express reluctance to change.

Even though the results did not reveal contradictions specific for eHealth context, this study has shown the importance of understanding the stakeholder interests in order to address emerging or potential conflicts. Further, our study illustrates the usefulness of combining ST and Dialectic Process Theory for identifying stakeholders and contradictions in eHealth efforts. This can be seen as the main contribution, as it supports practice to focus properly in a demanding reality. The analysis can be used as a tool for communication and coordination among the different stakeholders to prevent potential conflicts through the next phases of the projects similar to our case.

Implications", The Academy of Management Review, 20 (1995), pp. 65-91.

[10] A. Essén and M. Conrick, "New e-service development in the homecare sector: Beyond implementing a radical technology", International Journal of Medical Informatics, 77 (2008), pp. 679-688.

[11] G. Eysenbach, "What is e-health?", Journal of Medical Internet Research, 3 (2001), pp. e20.

[12] A. Faxvaag, P. Toussaint and T. S. Johansen, "Research management in healthcare informatics experiences from Norway", Stud Health Technol Inform, 169 (2011), pp. 980-4.

[13] L. S. Flak, S. Nordheim and B. E. Munkvold, "Analyzing Stakeholder Diversity in G2G Efforts: Combining Descriptive Stakeholder Theory and Dialectic Process Theory", e-Service Journal, 6 (2008), pp. 3-23.

[14] L. S. Flak and J. Rose, "Stakeholder Governance: Adapting Stakeholder Theory to E-Government", Communications Of The Association For Information Systems, 16 (2005), pp. 642-664.

[15] R. E. Freeman, J. S. Harrison, A. C. Wicks, B. L. Parmar and S. De Colle, Stakeholder theory: The state of the art, Cambridge University Press, 2010.

[16] N. F. Garmann-Johnsen and Ø. Hellang, Collaborative Process Modelling and Evaluation in E-health, Scandinavian Conference on Health Informatics Grimstad; Norway, 2014. 
[17] W. J. Grigsby, "Telehealth: An assessment of growth and distribution", Journal of Rural Health, 18 (2002), pp. 348-358.

[18] C. Henderson, M. Knapp, J.-L. Fernández, J. Beecham, S. P. Hirani, M. Beynon, M. Cartwright, L. Rixon, H. Doll, P. Bower, A. Steventon, A. Rogers, R. Fitzpatrick, J. Barlow, M. Bardsley and S. P. Newman, "Cost-effectiveness of telecare for people with social care needs: the Whole Systems Demonstrator cluster randomised trial", Age And Ageing, 43 (2014), pp. 794800.

[19] C. Henderson, M. Knapp, J.-L. Fernández, J. Beecham, S. P. Hirani, M. Cartwright, L. Rixon, M. Beynon, A. Rogers and P. Bower, "Cost effectiveness of telehealth for patients with long term conditions (Whole Systems Demonstrator telehealth questionnaire study): nested economic evaluation in a pragmatic, cluster randomised controlled trial", (2013).

[20] A. Hoerbst and M. Schweitzer, "A Systematic Investigation on Barriers and Critical Success Factors for Clinical Information Systems in Integrated Care Settings", IMIA Yearbook (2015), pp. 79-89.

[21] Investopedia, In-House, 2016.

[22] B. Kaplan, P. F. Brennan, A. F. Dowling, C. P. Friedman and V. Peel, "Toward an Informatics Research Agenda: Key people and organizational issues", Journal of the American Medical Informatics Association, 8 (2001), pp. 235-241.

[23] B. Lane and E. Gullone, "Common fears: A comparison of adolescents' self-generated and fear survey schedule generated fears", The Journal of genetic psychology, 160 (1999), pp. 194-204.

[24] R. D. Lasker, E. S. Weiss and R. Miller, "Partnership synergy: a practical framework for studying and strengthening the collaborative advantage", Milbank quarterly, 79 (2001), pp. 179-205.

[25] V. MacNeill, C. Sanders, R. Fitzpatrick, J. Hendy, J. Barlow, M. Knapp, A. Rogers, M. Bardsley and S. P. Newman, "Experiences of front-line health professionals in the delivery of telehealth: a qualitative study", The British Journal Of General Practice: The Journal Of The Royal College Of General Practitioners, 64 (2014), pp. e401e407.

[26] S. Martin, G. Kelly, W. G. Kernohan, C. Bernadette McCreight and S. Nugent, "Smart home technologies for health and social care support", Cochrane Database of Systematic Reviews (2008).

[27] L. Mathiassen and P. A. Nielsen, "Soft systems and hard contradictions", Journal of Applied Systems Analysis, 16 (1989), pp. 75-88.

[28] G. H. Mengesha, A. A. Kebede, M. J. Garfield and P. F. Musa, "Stakeholders Analysis of Ethiopian Telemedicine Projects: the case of Black Lion Hospital, Addis Ababa, Ethiopia Research-in-Progress".

[29] M. B. H. Miles, A. M. M. B. Miles and A. M. Huberman, An expanded sourcebook qualitative data analysis, 1994.

[30] C. Pagliari, "Design and evaluation in eHealth: challenges and implications for an interdisciplinary field", Journal of medical Internet research, 9 (2007), pp. e15.
[31] A. Pouloudi, "Information technology for collaborative advantage in healthcare revisited", Information \& Management, 35 (1999), pp. 345-356.

[32] Å. Ringard, A. Sagan, I. S. Saunes and A. K. Lindahl, "Norway: Health system review", Health Systems in Transition, 15 (2013), pp. 1-162.

[33] J. Segar, A. Rogers, C. Salisbury and C. Thomas, "Roles and identities in transition: boundaries of work and inter-professional relationships at the interface between telehealth and primary care", Health \& social care in the community, 21 (2013), pp. 606-613.

[34] H. Solli, I. Bjoerk, S. Hvalvik, R. Hellesoe and H. Solli, "Principle-based analysis of the concept of telecare", Journal of Advanced Nursing, 68 (2012), pp. 2802-2815.

[35] A. Steventon, M. Bardsley, J. Billings, J. Dixon, H. Doll, S. Hirani, M. Cartwright, L. Rixon, M. Knapp and C. Henderson, "Effect of telehealth on use of secondary care and mortality: findings from the Whole System Demonstrator cluster randomised trial", Bmj, 344 (2012), pp. e3874.

[36] S. Sävenstedt, P.-O. Sandman and K. Zingmark, "The duality in using information and communication technology in elder care", Journal of Advanced Nursing, 56 (2006), pp. 17-25.

[37] T. H. Van De Belt, L. J. Engelen, S. A. Berben and L. Schoonhoven, "Definition of Health 2.0 and Medicine 2.0: a systematic review", Journal of medical Internet research, 12 (2010), pp. e18.

[38] A. H. Van de Ven and M. S. Poole, "Explaining Development and Change in Organizations", Academy of Management Review, 20 (1995), pp. 510-540.

[39] M. J. van der Meijden, H. J. Tange, J. Troost and A. Hasman, "Determinants of Success of Inpatient Clinical Information Systems: A Literature Review", Journal of the American Medical Informatics Association, 10 (2003), pp. 235-243.

[40] J. E. van Gemert-Pijnen, N. Nijland, M. van Limburg, H. C. Ossebaard, S. M. Kelders, G. Eysenbach and E. R. Seydel, "A Holistic Framework to Improve the Uptake and Impact of eHealth Technologies", J Med Internet Res, 13 (2011), pp. e111.

[41] M. Van Offenbeek, A. Boonstra and D. Seo, "Towards integrating acceptance and resistance research: evidence from a telecare case study", European Journal of Information Systems, 22 (2013), pp. 434-454.

[42] J. Ward and E. Daniel, Benefits management: Delivering value from IS \& IT investments, John Wiley \& Sons Chichester, 2006.

[43] WHO, 10 facts of ageing and the life course, WHO, http://www.who.int/features/factfiles/ageing/en/, 2014.

[44] R. Wootton, "Twenty years of telemedicine in chronic disease management--an evidence synthesis", J Telemed Telecare, 18 (2012), pp. 211-20.

[45] Yourdictionary.com, Enthusiast, 2016. 